\title{
COVID-19 transmission, vulnerability, persistence and nanotherapy: a review
}

\author{
Afzal Husain Khan ${ }^{1} \cdot$ Vineet Tirth ${ }^{2} \cdot$ Manal Fawzy $^{3}$ (D) Alaa El Din Mahmoud ${ }^{3}$ - Nadeem A. Khan ${ }^{4}$ (D) \\ Sirajuddin Ahmed ${ }^{4}$. Syed Sadat Ali ${ }^{5}$. Muhammad Akram ${ }^{6}$. Leena Hameed ${ }^{12}$. Saiful Islam ${ }^{7} \cdot$ Gotam Das $^{8}$. \\ Sharmili Roy ${ }^{9} \cdot$ Mohammad Hadi Dehghani $^{10,11}$ [D
}

Received: 17 September 2020 / Accepted: 16 March 2021 / Published online: 7 April 2021

(c) The Author(s), under exclusive licence to Springer Nature Switzerland AG 2021

\begin{abstract}
End 2019, the zoonotic severe acute respiratory syndrome coronavirus 2 (SARS-CoV-2), named COVID-19 for coronavirus disease 2019, is the third adaptation of a contagious virus following the severe acute respiratory syndrome coronavirus in 2002, SARS-CoV, and the Middle East respiratory syndrome virus in 2012, MERS-CoV. COVID-19 is highly infectious and virulent compared to previous outbreaks. We review sources, contagious routes, preventive measures, pandemic, outbreak, epidemiology of SARS-CoV, MERS-CoV and SARS-CoV-2 from 2002 to 2020 using a Medline search. We discuss the chronology of the three coronaviruses, the vulnerability of healthcare workers, coronaviruses on surface and in wastewater, diagnostics and cures, and measures to prevent spreading.
\end{abstract}

Keywords Coronavirus $\cdot$ SARS-CoV-2 $\cdot$ Water $\cdot$ Wastewater $\cdot$ Health care center $\cdot$ Nanotechnology

\begin{tabular}{|c|c|c|c|}
\hline & & CDC's & \multirow{3}{*}{$\begin{array}{l}\text { Centers for disease control } \\
\text { and prevention } \\
\text { National Health and Medical } \\
\text { Research Council } \\
\text { International Agency for }\end{array}$} \\
\hline & $\begin{array}{ll}\text { Abbreviations } & \\
\text { SARS } & \begin{array}{l}\text { Severe acute respiratory } \\
\text { syndromes }\end{array}\end{array}$ & NHMRC & \\
\hline MERS-CoV, 2012, Saudi Arabi & $\begin{array}{l}\text { Middle East respira- } \\
\text { tory syndrome virus }\end{array}$ & IARC & \\
\hline $\mathrm{H} 2 \mathrm{H}$ & \multirow{2}{*}{$\begin{array}{l}\text { Human to human } \\
\text { World Health Organizations } \\
\text { Health care workers }\end{array}$} & & Research on Cancer \\
\hline $\begin{array}{l}\text { WHO } \\
\mathrm{HCW}\end{array}$ & & WEPA & $\begin{array}{l}\text { Water Environment Partner- } \\
\text { ship in Asia }\end{array}$ \\
\hline
\end{tabular}

Nadeem A. Khan

er.nadimcivil@gmail.com

$\triangle$ Mohammad Hadi Dehghani

hdehghani@tums.ac.ir

1 Civil Engineering Department, Jazan University, Jazan 114, Saudi Arabia

2 Department of Mechanical Engineering, King Khalid University, Abha 61413, Saudi Arabia

3 Environmental Sciences Department, Faculty of Science, Alexandria University, Alexandria 21511, Egypt

4 Civil Engineering Department, Jamia Millia Islamia (A Central University), New Delhi 110025, India

5 Department of Physiology, Faculty of Medicine, Jazan University, Jazan 114, Saudi Arabia

6 Department of Eastern Medicine, Government College University, Faisalabad, Pakistan
7 Civil Engineering Department, College of Engineering, King Khalid University, Abha, Kingdom of Saudi Arabia

8 Department of Prosthodontics, College of Dentistry, King Khalid University, Abha 61413, Saudi Arabia

9 Division of Oncology, School of Medicine, Stanford University, Stanford, CA 94305, USA

10 Department of Environmental Health Engineering, School of Public Health, Tehran University of Medical Sciences, Tehran, Iran

11 Center for Solid Waste Research, Institute for Environmental Research, Tehran University of Medical Sciences, Tehran, Iran

12 Faculty of Eastern Medicine, Hamdard University, Karachi, Pakistan 


$\begin{array}{ll}\text { DWAFSA } & \begin{array}{l}\text { South African Department of } \\ \text { Water Affairs and Forestry } \\ \text { National Public Health Ser- } \\ \text { vice for Wales } \\ \text { Real time-polymerase chain } \\ \text { reaction } \\ \text { Quantitative reverse } \\ \text { transcription-PCR }\end{array} \\ \text { rt-PCR/qPCR } & \begin{array}{l}\text { Rolling circle amplification } \\ \text { Aluminate-based } \\ \text { nanomaterials }\end{array} \\ \text { RCA } & \begin{array}{l}\text { Computer tomography } \\ \text { Next generation sequencing }\end{array} \\ \text { ALBO } & \text { Transmissible gastroenteritis } \\ \text { virus } & \text { QSS model }\end{array}$

\section{Introduction}

The severe acute respiratory syndromes (SARS) is from a lineage of $\beta$-coronaviruses that caused the emergence of previous outbreaks-SARS-CoV in 2002 in China, and the Middle East respiratory syndrome virus MERS-CoV in 2012 i nSaudi Arabia. The $\beta$-coronaviruses such as SARS-CoV and MERS-CoV can induce infection in the lower respiratory tract followed by cough and fever and that trends to cause severe respiratory illness in humans (CDC 2020). Whereas, recent pandemic by novel severe acute respiratory syndromes (SARS-CoV-2) is a fall in $\alpha$-coronavirus lineage showing similarity to these earlier CoV's such as SARS-CoV and MERS-CoV, predominately attacks alveolar epithelial cell of the lung, stimulates peripheral pneumoniacausing mass mortality up to 5\% (Wu et al. 2020c). This suggests that the clinical spectrum of SARS-CoV-2 is not confined to peripheral pneumonia, but relatively indicates a multiple series of illness leading to multiple organ failure such as heart, liver, kidney, coagulation, gut or gastrointestinal tract (Robba et al. 2020) that are highly contagious than previous illness by SARS-CoV or MERS-CoV in human (Tang et al. 2020).

Hence, we review SARS-CoV-2 in correlation to previous SARS and MERS outbreaks (Dai et al. 2020; Gorrasi et al. 2020; Choi et al. 2021). We present the key scientific developments, ongoing research and rapid detection procedures from the SARS-CoV and MERS-CoV outbreaks insights to understand the gravity of the problem for possible preventive measures to control the current pandemic (Sarkar et al. 2020; Sharma et al. 2020, 2021). In addition, we present an extensive outline of the outspreading of the SARS-CoV-2, aspects responsible to the transmission, vulnerability, persistence, and addressing potential control approaches in pandemic mitigation (Prabha et al. 2020; He et al. 2021;
Mousazadeh et al. 2021). The most innovative point of this review is the correlation of the behavioral patterns of the coronavirus family in different settings and its tenacity in the environment, which should facilitate the design of epidemiological measures to avoid such pandemics in future. This study also highlights the comparative study on symptoms and various laboratory methodologies and parameters. The major aspects are the following: (1) epidemiological findings across several countries contributing toward cross-cultural and scientific influences, (2) present vulnerability data of first line exposures, healthcare workers with case fatality among them, (3) persistence of agents such as material surfaces, water, wastewater, streams, and (4) finally provide some insights \& strategies learned from earlier outbreaks.

\section{Review methodology}

The main aim of this review is to make a combinative review information for better understanding the current state of SARS-CoV-2 situation. Therefore, we have used databases like PubMed, Google Scholar, Scopus, Web of Science, and Research gate. The adapted keywords were "coronavirus" and "virus name" such as "SARS-CoV," "MERS-CoV," "SARS-CoV-2," "COVID-19" and other strings like "epidemiological," "preventive measures," "transmission," "persistency," "vulnerability," "pandemic," "human to human transmission" and "nanotheraputics," etc. Furthermore, we have excluded the inappropriate studies and selected proper articles that were additionally checked for references which will increase the scientific values of this study. Besides, we accessed the websites of the world health organizations (WHO), Centers for Disease Control and Prevention guidelines, the Council of European Union, the Australian Government National Health and Medical Research Council (NHMRC), the Canadian Federal Provincial Territorial Committee on Health and the Environment, the International Agency for Research on Cancer (IARC), the National Standard of the People's Republic of China, the Japanese Ministry of Health, Labor and Welfare, the Water Environment Partnership in Asia (WEPA), the New Zealand Ministry of Health, the South African Department of Water Affairs and Forestry (DWAFSA), the National Public Health Service for Wales (NPHS), and various health ministry's information on COVID-19 (Sun and Han 2020; Wang et al. 2020a, c). The main goal of the current review is to provide clear and comprehensive information of coronaviruses infections and current status. Additionally, this study reviewed about newly developed methods, potential technologies and further mainly focused on nanotherapeutic approaches toward COVID-19 that has been discussed. 


\section{Natural virus hosts}

The human coronavirus 229E (HCoV-229E), human coronavirus NL63 (HCoV-NL63), human coronavirus OC43 (HCoV-OC43), human coronavirus (HCoV-HKU1), SARSCoV, MERS-CoV, and SARS-CoV-2 have a zoonotic origin from bats, mice, or domestic animals (Ye et al. 2020). SARS-CoV-2 has characteristics that are similar to SARS$\mathrm{CoV}$ and MERS-CoV which shows high communicable. Epidemiological data revealed civets raccoon dogs were the first carrier of SARS-CoV- viruses (Guan et al. 2003). A subsequent study showed that for a host of SARS-CoV revealed relation to bat $\mathrm{CoV}$ ( $\mathrm{Li}$ et al. 2005). Similar findings that showed MERS-CoV was closely relative to bat origin (Lau et al. 2018). Researches from Shanghai shown that the natural host is likely to be bat for SARS-CoV-2 (Ji et al. 2020). Further other studies from Perkin University suggested that snakes may be the cause (Ji et al. 2020). Later, studies try to prove that snakes were not the cause (Zhang et al. 2020a, b) and gene sequence between SARS-CoV-2 with bat coronavirus is high as $96.2 \%$ by sequencing technology (Yuen et al. 2020). These factors suggest that the possible cause of this virus could be a bat. According to findings published by the journal Nature Medicine, the novel SARS-CoV-2 is the product of natural evolution (Andersen et al. 2020). In the current situation, main sources of spread such as vulnerable population, risk groups, and factors, are considered to be affected population but is debatable regarding the incubation period and needed more research (Wang et al. 2020b).

\section{Clinical profiles of infected coronavirus patients}

The laboratory parameters and clinical profile in patients suffering from coronavirus infections are shown in Table 1.

Findings are essential to interpret the unknown deadly viruses and its behavior more efficiently to save the mankind. From the above-mentioned references, it is easy to understand the transmissibility of COVID-19 and the innate immune process behind this phenomenon. In the next section, we discuss various routes of transmission of coronaviruses.

\section{Route of transmission}

The first indication of human to human transmission was detected in SARS-CoV, develops primarily by nosocomial transmission. Similar indications were reported in MERSCoV; which were linked to hospitals (Chowell et al. 2015). The hospital transmission of MERS-CoV's was the most usual route of transmission of infection among patients up to $79 \%$, whereas up to $42 \%$ for SARS-CoV (Chowell et al. 2015). At present, spread of SARS-CoV-2 is substantially influenced by contact with the infected persons either via aerosol, airborne or object transmission (Adnan Shereen et al. 2020) (Baranwal, Mahapatra et al. 2020). This was proven by the detection of this virus in the various samples taken from the population through stool, urine and saliva. Considering the bioinformatics, digestive track is the main route of infection (Wang et al. 2020b). It was also seen

Table 1 Common symptoms in different countries having persistent infection detection of severe acute respiratory syndrome coronavirus 2 (SARS-CoV-2) and laboratory parameters

\begin{tabular}{|c|c|c|c|c|c|}
\hline \multirow[t]{2}{*}{ Symptoms } & \multicolumn{5}{|l|}{ References } \\
\hline & Huang et al. (2020) & $\begin{array}{l}\text { Wang et al. } \\
(2020 a)\end{array}$ & Chin et al. (2020) & Kong et al. (2020) & $\begin{array}{l}\text { Chan } \\
\text { et al. } \\
\text { (2013) }\end{array}$ \\
\hline Fever & $98 \%$ & $98.6 \%$ & N/A & $87.9 \%$ & $83 \%$ \\
\hline Dry cough & $76 \%$ & $59.4 \%$ & N/A & $67.7 \%$ & $82 \%$ \\
\hline Fatigue or myalgia & $44 \%$ & $69.6 \%$ & N/A & N/A & $11 \%$ \\
\hline Sputum formation & $28 \%$ & N/A & N/A & N/A & N/A \\
\hline Diarrhoea & $3 \%$ & N/A & N/A & Seldom & $2 \%$ \\
\hline Haemoptysis & $5 \%$ & N/A & N/A & N/A & N/A \\
\hline Distress syndrome & $29 \%$ & $61.1 \%$ & N/A & N/A & $17 \%$ \\
\hline Shock & N/A & $30.6 \%$ & N/A & N/A & N/A \\
\hline Lymphopenia & $63 \%$ & $70 \%$ & N/A & $82.1 \%$ & N/A \\
\hline Ground-glass lung opacities & $100 \%$ & $100 \%$ & $100 \%$ & $50 \%$ & $14 \%$ \\
\hline Symptom onset, day & Up to 8 & N/A & N/A & Median period $3(1-24)$ & N/A \\
\hline
\end{tabular}

N/A not applicable 
that pregnant women with COVID-19 virus likely to infect infants through intrauterine vertical transmission (Chen et al. 2020a). Few studies stated that the airborne transmission through aerosols route is highly infectious and dominant for the spread of COVID-19 (Zhang et al. 2020a, b). Inhaling the virus-bearing aerosols effecting human respiratory tract directly. The inadequate awareness on SARS-CoV-2 virus hindered this pandemic globally. However, to establish these hypotheses, researchers are trying to do more experimental studies since such studies are very limited and require more verification. Until then, the development of effective mitigation policies and measurements to stop this virus has to be taken very seriously.

\section{Vulnerability to healthcare workers}

Recent epidemiological studies suggest that elderly people i.e., 75 years and above are more vulnerable as compared to other age groups toward SARS-CoV-2 (Bonafè et al. 2020; Rabaan et al. 2020; Chandra and Roy 2020). Considering clinical aspects of COVID-19, the probable incubation period was 3 days having death symptoms in 14 days for the elderly persons were reported (CDC 2020). If we look at SARS cases, it was 4 days and 17.4 days for first death symptoms to be visible (Cho et al. 2016). Moreover, it is worthy to note that the incubation period for SARS-CoV-2 is quite shorter than another coronavirus like SARS and MERS. Additionally, 24 days of high inactivity toward transmission is also been observed. Besides, another trend was observed that 20 days for the first death symptoms arise, as a median for the aged person above 70 years and 11.5 days as shorter median. From the above, it would be suggestive that for an elderly person is more likely to get infected as compared to other hence needed to take special precautions.

According to United States-Centers for Disease Control and Prevention (US-CDC), the risks faced by healthcare workers were very high, even with protective gear, as they had a very intimate relationship with their patients. The infectious materials have potential vulnerability in direct/ indirect transmission to patients comprising (1) body substances, (2) infected medical tools and instruments, (3) infected material surfaces, and (4) aerosols transmissions.

Among all the three coronaviruses, SARS-CoV-2 is the most infectious followed by MERS-CoV, SARS-CoV, respectively, as reported by World Health Organizations. To date, the healthcare workers accounted infected (deaths) by SARS-CoV-2, MERS-CoV and SARS-CoV are around 1706 (41), 450 (24), and 287,010 (2000) (WHO 2019; Xiao et al. 2020). According to the International Council of Nurses, so far more than 90,000 Healthcare workers have been infected by SARS-CoV- 2 and more than 260 nurses died. Hence, the total numbers of deaths among healthcare workers are hard to access by, but to date, more than 2000 healthcare workers died globally on treating COVID-19 patients as shown in Table 2.

Healthcare workers should take all the precautions to learn from former coronaviruses (MERS, SARS) experiences for the prevention and cure of future outbreaks. High fatality in SARS-CoV-2 indicates less understanding, and implementation in handling indicates that a thorough workup from earlier outbreaks such as SARS and MERS, causing patients, hospitals, and healthcare worker vulnerability is required.

Therefore, the vulnerability is very serious for SARSCoV-2. Moreover, this virus is airborne which has great mobility, long surviving nature and duration of time for dispersion is quick. Due to these reasons, SARS-CoV-2 is more vulnerable specially in densely populated countries or areas.

\section{History of coronaviruses}

In the early twenty-first century, in 2003, SARS-CoV emerged in China and a decade later in 2012 MERS-CoV was first diagnosed in Saudi Arabia. Recently, close to 2020, a new chain of SARS-CoV-2 emerged again in Wuhan, China in December 2019 with a similar character that caused the SARS outbreak in 2002. Hubei provinces, Wuhan is a hub of wholesale food markets in Huanan that supply bat soup. A medical team headed by Zheng-Li Shi consists of microbiologists that isolated the virus from a 49 -year-old lady. Li Wenliang posted warnings to their colleagues and associate staff, that an unknown virus has been developed within the province of city and Hubei provinces that is similar to SARS and MERS. He stated that symptoms were fever, sore throat, and sneezing by the lady within the hospital. This novel SARS-CoV-2 is the most outreaching among all the three coronaviruses and has infected more than 200 countries so far. The coronaviruses represent a various family of positive sense ribonucleic acid (+ ssRNA) viruses capable of inflicting metastasis and enteric sickness in deferent hosts. Although, many human coronaviruses are known to cause gentle metastasis disease ( $\mathrm{Li} 2015$ ), most capable of inflicting a severe respiratory illness by infecting humans such as SARS and MERS CoV's. The SARS-CoV arose into humans in 2002, infected around 37 nations throughout its course for more than nine-month circulation in humans (Liu et al. 2020). This epidemic led to more than 8000 confirmed contagions with above $10 \%$ mortality and it was thought SARS-CoV had been eliminated until the death of recent humans with infections (Ge et al. 2013).

In 2012, another nexus of member beta-coronavirus subgroup MERS-CoV epidemic was originated in Saudi Arabia, from a patient with mucous secretion and acute respiratory 


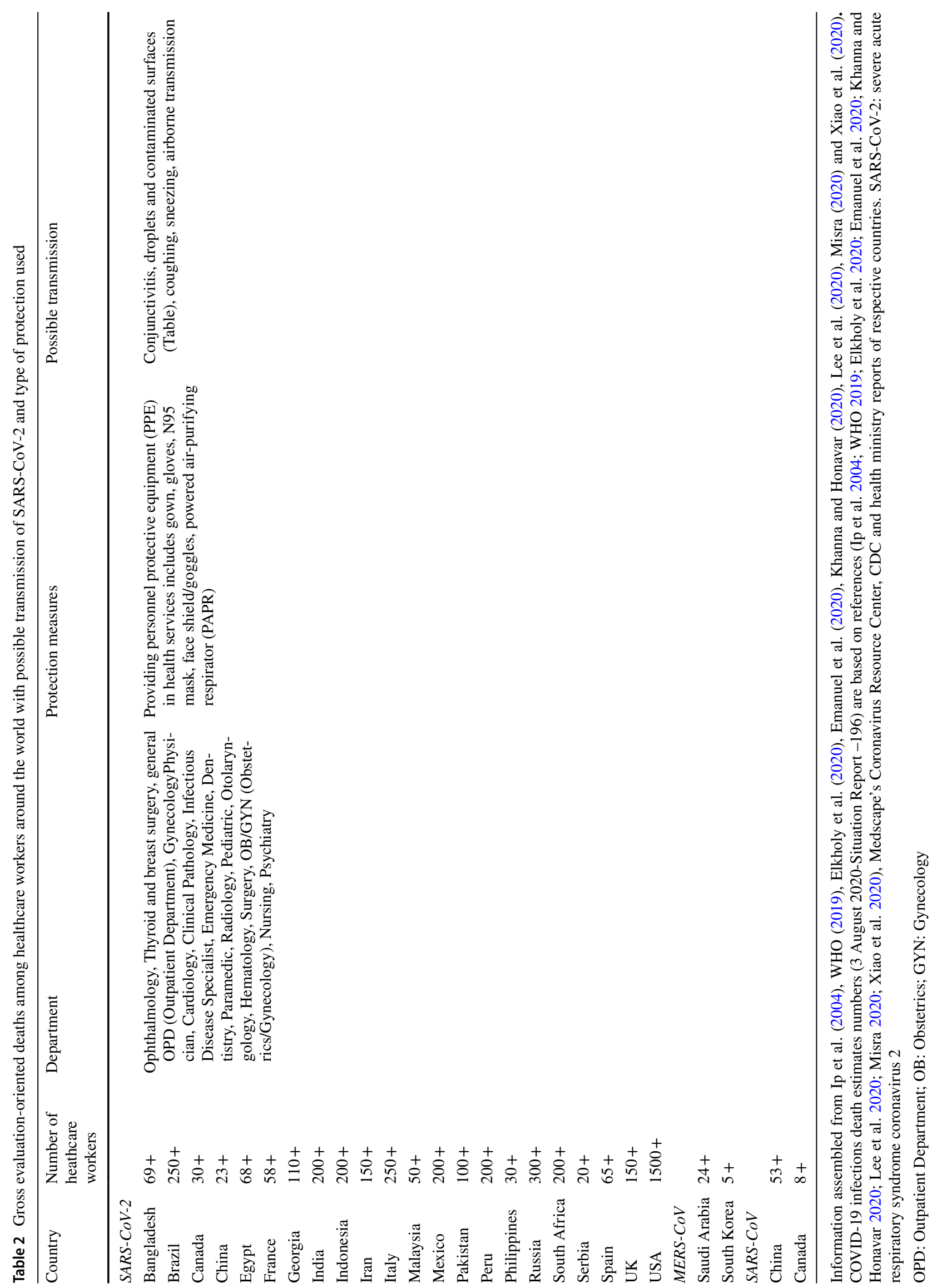


disease and nephropathy (Pavli et al. 2014). Typical symptoms were myalgia, abdominal pain, vomiting and diarrhea, and some symptoms similar to SARS-CoV such as shortness of breath, cough, sore throat, pneumonia, rigors, and fever (Assiri et al. 2013). Its fatality rate was very high and approximately one-third of infected patients died. According to World Health Organizations (WHO), more than 2494 individuals have been infected and more than 858 deaths worldwide have occurred due to MERS-CoV to date (Rahman and Sarkar 2019). The authors reported that several MERS-CoV patients in Saudi Arabia were from healthcare unit transmission and few secondary cases occurred following close contact to infected patients with severe symptoms (Pavli et al. 2014). Researchers found that the majority of MERS-CoV patients had been infected indirectly by individuals with MERS-CoV symptoms (Hui et al. 2018). Results of a later study show that there are hardly any remedial compounds for MERS-CoV, containing a synthesis of lopinavir/ ritonavir (LPV/r) and Betaferon, and ribavirin (Momattin et al. 2019). Consequently, precautionary action is only to reduce the risk of spread.

Additionally, the evolution of SARS-CoV-2 is similar to MERS-CoV and SARS-CoV which is genetically associated to have a zoonotic origin. According to the Chinese Centers for Disease Control and Prevention, the patient diagnosed with virus infection may have visited the infected Wuhan seafood market. Recent investigations have been also stated that newly infected individuals may have approached the infected patient, not visiting the Wuhan market (Adnan Shereen et al. 2020). In the month of January, World Health Organizations (WHO) took the necessary step and declared COVID-19 as a global pandemic worldwide. The intervention in-order to stop the spread lies with the fact of how quick people can respond to this emergency, the early detection, the early treatment, isolation procedures with rugged implementation (Peck 2020). The major symptoms detected during this outbreak in Wuhan were flu like symptoms such as dry cough, persistent fever, and lung infiltration (Sohrabi et al. 2020). They majorly linked to the seafood initially and related live stocks like bats and snakes (Lu et al. 2020a). Recently, some of such problems resolved instantaneously but mainly in selected cases these developed symptoms converted into fatal injuries i.e., septic shock, acute respiration problems, and organ failures. Some extensive studies assisted that more than 54\% are male infected patients (Chen et al. 2020b).

Based on the results to date, the human transmission potential of this virus unfurls COVID-19 to more than 200 countries in the world. According to the World Health Organization's (WHO) report, globally 93,217,287 have been infected and 2,014,957 deaths from the coronavirus have been confirmed to date. The COVID-19 conditions in America, India, and Brazil are continuously worsening, so far total infected and deaths are $23,344,423(389,084)$, $10,557,985(152,274)$ and 8,393,492 $(208,246)$ were recorded highest in the world, respectively. The fatality rate is highest in the America region i.e., 3.6\% (Culp 2020). A comparative analysis of coronaviruses SARS-CoV, MERS$\mathrm{CoV}$, and SARS-CoV-2 is shown in Table 3.

Thus, in the last two decades, human population has faced three coronaviruses outbreaks. These viruses can affect children and adults severely. However, in the case of SARSCoV-2, children showed mild symptoms than adults. Many studies have been conducted to know the zoonotic origin of three coronaviruses after continuous attacks of these viruses. In the later section, we have focused on how coronaviruses are spreading from various surfaces, objects and solid materials to human.

\section{Coronavirus persistence on surfaces}

The studies have been done concerning the persistency of coronaviruses on several materials surfaces, such as aluminum, aerosols, copper, cardboard, disposable gown, metal, paper, plastic, steel, surgical glove, and wood. The virus existence varies from $2 \mathrm{~h}$ to 5 days and the temperatures ranging from 20 to $25^{\circ} \mathrm{C}$ as shown in Table 4 . A higher persistence showed by SARS-CoV on metals that are capable to exist for 5 days. After considering the research studies, comparative data were collected regarding the persistency of the higher side of the inoculation and is presented in Table 4. According to van Doremalen et al. (2020), it has also been observed that different surfaces have different surface stability concerning that of SARS-CoV-2 and SARS-CoV when compared on aerosol, plastic, steel, disposable gown, and cardboard. Both the CoV's (SARS-CoV-2 and SARS-CoV) remained capable of attaching onto aerosols for a span of $3 \mathrm{~h}$. SARS-CoV-2 stability on common surfaces of plastic for that of stainless steel was observed more than on copper and cardboard and is stable up to 3 days. The constancy kinetics of SARS-CoV were analogous after 3 days on plastic and after 2 days on stainless steel. It has been observed that on copper and cardboard, no valid SARS-CoV-2 was detected after $4 \mathrm{~h}$ and $24 \mathrm{~h}$, respectively. Similarly, no valid SARS-CoV was detected after $8 \mathrm{~h}$ on copper and cardboard, respectively (van Doremalen et al. 2020; Carraturo et al. 2020; Wang et al. 2020d, e).

An investigation showed the persistency of HCoV-229E is inactive within $1 \mathrm{~min}$ on stainless steel, using ethanol $70 \%$ w/v or $0.1 \%$ sodium hypochlorite (Kampf et al. 2020). Based on the previous investigation on SARS-CoV and MERS$\mathrm{CoV}$, reported no infections transmitted through food, vegetables (Vasickova et al. 2010; Yépiz-Gómez et al. 2013). However, the authors reported stable pathogens at low temperatures. Hence, avoiding uncooked food and scientific 
Table 3 Comparison of coronaviruses

\begin{tabular}{llll}
\hline Coronaviruses & SARS-CoV & MERS-CoV & SARS-CoV-2 \\
\hline Origin & Guangdong, China & Zarqa, Jordan & Wuhan, China \\
Date & November, 2002 & April, 2012 & December, 2019 \\
Natural hosts & Bat, palm civets and Raccon dogs & Bat, camel & Bat, snake \\
Transmission mode & Zoonotic virus & Zoonotic virus & Zoonotic virus \\
Receptor recognition & ACE2 & DPP4 & ACE2 \\
Infected countries & 37 & 27 countries & $235+*$ \\
Infected (deaths) & 8000 (800) & 2494 (858) & $93,217,287$ (2,014,957) \\
Symptoms & Fever, malaise, myalgia, diarrhea,, & Fever, Sore throat, & Cough, fever and shortness of breath, vomiting, diarrhea \\
& shivering, cough and shortness & cough, pneumonia, & \\
& of breath & shortness of breath, & \\
& diarrhea & \\
Vaccine developed & Under development** & Under development** & Under development** \\
Mortality rate & $10 \%$ & $35 \%$ & $\sim 5 \% *$ \\
$R 0$ & 0.80 & 0.5 & $2.43-3.10$ \\
References & Wang et al.(2005a, b), Cui et al. & Assiri et al. (2013), Cui & Adnan Shereen et al. (2020), Lu et al. (2020a, b) and \\
& (2013) and Adnan Shereen et al. & et al. (2013), Alfaraj & Wu et al. (2020a, b, c) \\
& (2020) & et al. (2019) and Ji & \\
& & (2020) & \\
\hline
\end{tabular}

*Data deprived from WHO Coronavirus disease (COVID-19) as of 19 January 2021-Situation Report

**No effective vaccine has been approved yet

R0-pathogen's basic reproductive number

Table 4 Coronaviruses persistency on various surfaces under different environmental conditions

\begin{tabular}{|c|c|c|c|c|c|}
\hline Surface $^{\mathrm{a}}$ & Virus & Strain & Temperature $^{\mathrm{b}}$ & Duration of existence & References \\
\hline Aluminum & $\mathrm{HCoV}$ & $229 \mathrm{E}$ & $21^{\circ} \mathrm{C}$ & 2 to $8 \mathrm{~h}$ & Sizun et al. (2000) \\
\hline Aerosols & SARS-CoV-2 & MN985325.1 & $21-23{ }^{\circ} \mathrm{C}$ & $3 \mathrm{~h}$ & van Doremalen et al. (2020) \\
\hline \multirow[t]{2}{*}{ Copper } & SARS-CoV & AY274119.3 & & $3 \mathrm{~h}$ & \\
\hline & SARS-CoV-2 & MN985325.1 & $21-23{ }^{\circ} \mathrm{C}$ & $4 \mathrm{~h}$ & van Doremalen et al. (2020) \\
\hline \multirow[t]{2}{*}{ Cardboard } & SARS-CoV & AY274119.3 & & $8 \mathrm{~h}$ & \\
\hline & SARS-CoV-2 & MN985325.1 & $21-23^{\circ} \mathrm{C}$ & $24 \mathrm{~h}$ & van Doremalen et al. (2020) \\
\hline \multirow[t]{2}{*}{ Disposable gown } & SARS-CoV & AY274119.3 & & $8 \mathrm{~h}$ & \\
\hline & $\mathrm{HCoV}$ & GVU6109 & $21{ }^{\circ} \mathrm{C}-22^{\circ} \mathrm{C}$ & $<2$ days & Lai et al. (2005) \\
\hline Metal & SARS-CoV & P9 & Room temperature & 5 days & Casanova et al. (2010) \\
\hline Paper & SARS-CoV & P9 & Room temperature & 4 to 5 days & Lai et al. (2005) \\
\hline \multirow[t]{3}{*}{ Plastic } & SARS-CoV-2 & $\begin{array}{l}\text { Isolate HCoV-EMC, } \\
\text { MN985325.1 }\end{array}$ & $22^{\circ} \mathrm{C}-25^{\circ} \mathrm{C}$ & $<5$ days & $\begin{array}{l}\text { (Chan et al. 2011; Kampf et al. } \\
\text { 2020; van Doremalen et al. } \\
\text { 2020) }\end{array}$ \\
\hline & MERS-CoV & & & & \\
\hline & SARS-CoV & AY274119.3 & & 3 days & \\
\hline \multirow[t]{3}{*}{ Steel } & SARS-CoV-2 & MN985325.1 & $21-23{ }^{\circ} \mathrm{C}$ & $48 \mathrm{~h}$ & van Doremalen et al. $(2013,2020)$ \\
\hline & SARS-CoV & AY274119.3 & & $48 \mathrm{~h}$ & \\
\hline & MERS-CoV & Isolate $\mathrm{HCoV}$-EMC & $20{ }^{\circ} \mathrm{C}$ & $48 \mathrm{~h}$ & \\
\hline Surgical glove (latex) & $\mathrm{HCoV}$ & $229 \mathrm{E}$ & $21^{\circ} \mathrm{C}$ & $<8 \mathrm{~h}$ & Sizun et al. (2000) \\
\hline Wood & SARS-CoV & P9 & RT & 4 days & Carraturo et al. (2020) \\
\hline
\end{tabular}

${ }^{a}$ Surface can be disinfected by simple disinfectant to kill the virus and ${ }^{\mathrm{b}}$ Exposure may also depends upon humidity of the environment H-CoV: Human coronavirus; SARS-CoV: Severe acute respiratory syndrome coronavirus; SARS-CoV-2: Severe acute respiratory syndrome coronavirus-2; EMC: Erasmus Medical Center 
studies recommended to cook foods above $70{ }^{\circ} \mathrm{C}$ to ensure the maintenance of healthy and hygienic factors (Carraturo et al. 2020).

Above-mentioned data demonstrate the severity of SARS$\mathrm{CoV}-2$ infections and its easy dispersion from various metal objects, solid surfaces, etc. Study said, this virus can be recovered from non-porous surfaces for maximum 28 days at $\sim 20{ }^{\circ} \mathrm{C}$ temperature and humidity. The transmission of this virus is not only spreading from aerosols or solid surfaces, but researchers have also found traces of virus in water and wastewater as well. Henceforth, we have discussed the presence of coronaviruses in water and wastewater in the following section.

\section{Coronavirus persistence in water and wastewater}

Several researchers found CoV's such as SARS-CoV, MERS-CoV, and SARS-CoV-2 RNA in the various sample of stool, urine, hospital wastewater, domestic wastewater, and stream water in Australia, China, France, Germany, Israel, Italy, India, the Netherland, Japan, Spain, Turkey, and USA (Wang et al. 2005b; Drosten et al. 2013; Pinon and Vialette 2018; Haramoto et al. 2020; Khan et al. 2020a; Randazzo et al. 2020; Alpaslan Kocamemi et al. 2020; Wu et al. 2020b; Kumar et al. 2020; Medema et al. 2020; Carraturo et al. 2020). Thus, wastewater-based epidemiology for the monitoring of coronavirus infections is much needed to prevent it in communities. Besides, the safety aspect should be considered in sampling wastewater, containing all PPE with protective sampling kits to avoid exposure to pathogens. Nevertheless, the presence of CoV's in the feces, urine, and blood of a diseased person is therefore not unexpected, as reported researchers that SARS-CoV and MERS-CoV RNA in stool specimens gathered on 12 and 16 days comprised the virus (Drosten et al. 2013). Recently, authors observed SARS-CoV-2 RNA in the stool sample of patients in the current global pandemic (Amirian 2020). However, vitro observations demonstrated that SARS-CoV virus persistence for 2 days, 3 days, and 14 days in hospital wastewater, feces, and urine, respectively, at $20^{\circ} \mathrm{C}$ (Wang et al. 2005b). In another study, the authors reported that SARS-CoV-2 RNA may be released through urine depending on the severity of patients. Besides, only $10 \%$ ( 2 of 20 patients) urine samples were detected SARS-CoV-2 RNA (Nomoto et al. 2020).

However, complete inactivation of SARS-CoV by adding residue chlorine over $0.5 \mathrm{mg} / \mathrm{L}$ (pure- $\mathrm{Cl}$ ) or $2.19 \mathrm{mg} / \mathrm{L}$ for chlorine dioxide in wastewater while insignificant reduction of $E$. coli and $\mathrm{f} 2$ phage was reported (Wang et al. 2005b). Additionally, the chlorination disinfection approach requires to be monitored carefully for possible ecological risks of disinfection by-products (Mazhar et al. 2020). However, from the treatment aspects, very limited treatment processes in removing or inactivating coronaviruses are available. This knowledge gap could be further investigated to ensure public health by monitoring wastewater treatment plants. Henceforth, additional crucial steps in research and managements are required to comprehend the possible presence of coronavirus or any other deadly viruses in normal drinking water or wastewater (Wang et al. 2005b; Mazhar et al. 2020; Nomoto et al. 2020).

\section{Diagnosis and treatment of SARS-CoV-2}

The current situation of SARS-CoV-2 is known for its rapid spread because the virus can tolerate harsh environmental conditions for up to $72 \mathrm{~h}$. Hence, increasing global concern on how to battle coronavirus calls for a novel therapeutic strategy (Sampath Kumar, Chintagunta et al. 2020). In this respect, the use of the ever-evolving options offered by nanotechnology seems to be promising solutions against emerging pathogens including SARS-CoV-2. Nanotechnology can be exploited for quick diagnosis of coronavirus as well as the development of drug delivery treatment (Vazquez-Munoz and Lopez-Ribot 2020).

Due to the SARS-CoV-2 outbreak, fast and accurate diagnostic tools are instantly required to screen COVID-19 patients and confirm the positive cases (Abdul et al. 2020). The common and mostly used bio-molecular based diagnosis of SARS-CoV-2 are nucleic acid detection by realtime-Polymerase Chain Reaction using quantitative reverse transcription-PCR (rt-PCR/qPCR), various isothermal amplification such as loop-mediated isothermal amplification (LAMP), rolling circle amplification, nucleic acid sequence based amplification (NASBA) etc. and screened via Computer tomography scans for lungs (Yang et al. 2020) (Roy and Baranwal 2020). Furthermore, to study the behavior of SARS-CoV-2 genome and gene analysis is performed by next generation sequencing (NGS). In addition, enzymelinked immunoassay (ELISA) based serological testing of SARS-CoV-2 is also available which is also used for surveillance tools for understanding the epidemiology of this virus (Kontou, Braliou et al. 2020). Antibody-antigen testing of viral elements is crucial to study about the clinical complications and existence cause of virus. However, these methods have many drawbacks such as these processes require high-end equipment, many costly reagents, trained/skilled laboratory personnel.

Therefore, nanotechnology and nanobiosenors can play a major role in producing scalable and inexpensive detection methods (Roy, Malode et al., Purohit, Kumar et al. 2019, Mahapatra, Baranwal et al. 2020, Shetti, Malode et al. 2020). Nano-biosensors can be used as a challenging point of care diagnostic tools even before symptoms have been shown in 
patients with very low viral loads (Abdul et al. 2020). Zhu et al. (2020) stated a new study about optical bio-nanosensor that can detect the coronavirus in $\sim 30$ min directly from patient's samples without needing centralized laboratory tests. Furthermore, it can track the evolution of viruses and prevent future outbreaks (Zhu et al. 2020). Recently, thermal biosensor-based SARS-CoV-2 detection with geotagging became very influential technique for the current scenario (Reichberg, Mitra et al. 2020). Many countries have applied this technology to separate infected personnel from healthy people in terms of controlling the transmission of this virus (Rodriguez-Manzano, Malpartida-Cardenas et al. 2021).

Generally, the key factor in using nanomedicine is the nanosize of the materials, which facilitate the penetration into the living cells. Besides, nanomaterials can play a defensive role, preventing the encapsulated drug or antiinfection agent from degradation because of the shielding properties of these nano-sized materials (Wang et al. 2018).

Drug delivery has major obstacles to reach the upper respiratory tract including lower blood flow, smaller surface area, mucus layer, and filtration of foreign objects. However, the lower respiratory tract may be an ideal area for the delivery because it is connected directly to the systemic circulation via pulmonary circulation and overcome a few challenges like branched nature alveolar macrophages and pulmonary surfactant. To address these barriers, nanotechnology-based approaches can be implemented due to their characteristic features such as small size and high surface area (Khan et al. 2020b; Mahmoud 2020a, b; Nikaeen et al. 2020).

Oxygen therapy via a ventilator plays a major role in the SARS-CoV-2 treatment but it is not enough. Nanotechnology can provide a substantial role in the treatment process. Nanoparticles could be integrated into the development of nano-based therapeutic agents or vaccines against several types of coronaviruses. This is due to various phytosynthesized nanoparticles that possess antiviral and antibacterial activities to reduce the disease risk. AbdelHamid et al. (2013) highlighted that gold, silver, and Au-Ag bimetallic nanoparticles have antibacterial activities. Ag showed antibacterial activity against $E$. coli and $S$. aureus bacteria (AbdelHamid et al. 2013; Gomathi et al. 2017; Sudha et al. 2017).

Due to the smaller average size of Silver nanoparticles $(\sim 20 \mathrm{~nm})$ than the average size of SARS-CoV-2 $(120 \mathrm{~nm})$, Silver nanoparticles can interact with the whole virus. Sportelli et al. (2020) reported the ability of Silver nanoparticles to inhibit the viral entry in host cells as with the HIV-1 virus, interact with cell receptors, and inhibit the viral replication (Sportelli et al. 2020). In 2020, the global consumption for health care-related nanotechnology is expected $>50$ tons, just for Silver nanoparticles (Salmiati et al. 2017).
Currently, the production of antibacterial papers impeded with silver nanoparticles is an international target because Silver nanoparticles can reduce SARS-CoV-2 $>95 \%$ from the paper surface (Patel 2020).

We should keep in mind that COVID-19 is one of the viral diseases, not bacterial infections which are still a serious challenge in the medical field. Au nanoparticles conjugated to a swine transmissible gastroenteritis virus (TGEV) in mice/rabbits could be considered as a potential antiviral candidate for vaccine application (Staroverov et al. 2011).

Viral infections pose substantial global health challenges by affecting millions of people worldwide, with negative consequences on socio-economic development (Singh et al. 2017). Nanoparticles have been proven to be effective in the inhibition of viruses regardless of their viral structures and their drug-resistant profile. The unique properties of nanoparticles favor drug delivery and entry through the negatively charged cell membrane. This can be due to their small particle size (affects bioavailability), their large ratio of surface area to volume, and their surface functionalization. Besides, they can have biomimetic properties as in the case of dendrimers which can encapsulate several chemical moieties (Cagno et al. 2018).

Nanotechnology-based viral disinfectants have great potential to prevent the virus dissemination. Various nanomaterials can be used to promote surface oxidation by releasing toxic ions and therefore preventing viral dissemination by inhibiting binding/penetration of viral particles, either by a generation of reactive oxygen species and/or photothermalbased reactions such as heat that destroy viral membranes (Talebian et al. 2020). One approach to fight against the virus is through preventing its dissemination through disinfecting air, skin, or surrounding surfaces (Talebian et al. 2020).

Another very important and exclusively used nanomaterial is graphene in the medical fields, it possesses viral inhibition capacity. However, few studies focused on the anti-viral efficiency of graphene nanomaterials. Graphene Quantum Dots have great potentials as HIV Inhibitors when conjugated with the non-nucleoside reverse transcriptase inhibitor (CDF119) (Iannazzo et al. 2018). (Ye et al. 2015) tested the antiviral effect of graphene oxide on the pseudorabies virus, PRV (causes Aujesky's disease). They detected that the virus is inactivated due to its direct interaction with the sharp edges of the graphene oxide layers (Ye et al. 2015). The negative charge of graphene oxide favors electrostatic interaction with the positively charged virus and higher interactions result in the destruction and inactivation of viruses (inhibitory effect) (Innocenzi and Stagi 2020).

Even nanocomposites are now widely preferable in drug delivery and medicinal applications. For instance, GO-Ag nanocomposites increase the biocompatibility of the materials and lessening the toxicological effects of the nanosilver 
as a metallic nanoparticle. Chen et al. (2016) found that graphene oxide only inhibited $16 \%$ of infection by a feline coronavirus, FCoV (represents enveloped virus) but showed no antiviral activity against infectious bursal disease virus, IBDV (non-enveloped virus) whereas Go-Ag inhibited 25\% of infection by FCoV and 23\% by IBDV (Chen et al. 2016).

It is noting that graphene oxide- $\mathrm{Ag}$ nanocomposite showed higher efficiency when compared with graphene oxide during the process of restraining viral infection. As graphene oxide sheets are negatively charged (Mahmoud 2020a, b), they can interact with the positively charged lipid membranes and $\mathrm{Ag}$ can bind to the sulfur groups of the viral proteins to impede the infection (Nikaeen et al. 2020).

The target mechanisms of nanoparticles are important for the drug delivery system. There are two types of targeting mechanisms. Active targeting requires the direct attachment of ligand as peptide/antibody to the nanotherapeutic of specific receptors. On the other hand, passive targeting can occur due to increased permeability or leakiness of the local vasculature which is caused by malignancy or inflammation (Singh et al. 2017). This results in the diseased area becoming more permissive to the accumulation of the nanotherapeutic agent.

The integration of nanomaterials is possible in the facemasks as it has become obligatory to wear them in public places. Unfortunately, the used facemasks are often very low quality and even N95 filters have very low protection efficiency against SARS-CoV-2 (Jokanovic et al. 2020). Recently, Jokanovic et al. (2020) concluded that their new aluminate-based nanomaterials (ALBO) nanosilver masks have significant advantages as they are safe and the sizes of $\mathrm{Ag}$ nanoparticles are in the range of 3-10 $\mathrm{nm}$ which can have high activity against viruses and bacteria. Hence, it can be concluded that researchers, are trying to get a cure for SARS-CoV-2 at the earliest. Many companies have already released various types of vaccines worldwide which were produced using these new molecular technologies and nanoparticles-based methods. In near future, there will be an exceptional implementation with advanced artificial intelligence-based technologies that will help to cure these deadly viruses in a fast and robust way.

\section{Mitigation and prevention}

Flatten the growth curve of COVID-19 is the aim of many countries. Hence, the lockdown was applied and was at the forefront of these restrictions. Herein, we highlight some examples. China essentially authorized a country-wide shut down and built an isolation hospital within a week with around 7000 workers operating day and night. Another precaution strategy was adopted by developing a stadium in
$24 \mathrm{~h}$ to quarantine/isolate the infected individuals (WHO 2020).

In USA, Florida initiated executive orders mandating the closure of beaches, large-scale community areas, and in-house dining as well as requiring expansion of hospital capacity. Florida authority recommends providing public health advisories about measures that can be taken to protect against COVID-19 (Sen-Crowe et al. 2021). Serological testing enhances the efficacy of early detection and medical action, including (WHO 2020) a meta-analysis. Scientific reports showed that serological examination accuracy COVID-19 can be attained by quality clinical studies (Lisboa Bastos et al. 2020). South Korea adopted maximum testing for the drivers and the authority could test around 300,000 individuals representing $17 \%$ of the total population. The prophylactic measures also control the transmission among communities. Common precaution strategies are applied and obligatory to everyone such as wearing masks outside, adopting alcohol-based hand sanitizer's, and supporting online working from home (WHO 2020).

The fever detection at the entry point by thermal scanning can be the most effective measure. It has been reported that spraying alcohol-based disinfectants in the air could tend to reduce the health risk to the masses (Syafiuddin et al. 2012; WHO 2020). Prevention and control need a multifactorial approach. Potential sources of infection both from humans or animals must be identified and separated. Furthermore, essential measures such as rinsing hands with detergents, social distancing (three feet), touching eyes, nose, and mouth should be restricted (Watkins 2020).

Recently, endorsing the QSS model (Quarantine, shield, and stop) by the governments/health ministry's helps in resilient infection in the community. Countries that strictly implement the QSS model will get better and recover with fruitful results within a short time such as China and Korea. Another important aspect in controlling pandemic is by halting travelers. Recently, Saudi Arabia, restricted religious activity (Annual Hajj) to 1000 domestic pilgrims (without international travelers) that usually packed with 3-5 million pilgrims, to prevent secondary transmission of COVID-19 into the kingdom (Memish et al. 2020).

\section{Conclusion}

The chronological follow-up study of SARS-CoV (2003), MERS-CoV (2012), and recent SARS-CoV-2 provides important insights in combatting SARS-CoV-2 infection. The research domain thrives for such a comparison between the characteristics of SARS-CoV-2 infection with these two CoV's. The recent outbreak unveiled the inadequate infrastructure in our health care system, especially of awareness for handling emerging global pandemic. Human 
to human transmission was one of the key transmission attributes of SARS-CoV, MERS-CoV, and SARS-CoV-2 infection and could be transmitted via heterophil-mediated communication, patient-to- Health Care Workers (HCW), Health Care Workers (HCW)-to-patient, and Health Care Workers (HCW)-to-Health Care Workers (HCW). The introspection for loose referral systems, such as travel restrictions, overcrowding at public areas especially in an emergency, infectious units, intensive care unit and respiratory section, lack of expertise in infection control sections, and improper control for health pandemic alarm the governing bodies to improve the healthcare system, and to spend much in controlling infectious diseases.

Some insights strategies and lessons we have learned so far, to prevent COVID-19 spread that includes:

- A sole skip in testing may trigger an outbreak

- Imposed mandatory thermal scanning of all areas including small shops, clinics/hospitals and public places

- Construction of an isolation unit. China build an isolation hospital within a week with around 7000 workers operating day and night

- Maximum testing. South Korea adopted drive-through testing and tested $17 \%$ of total population-around 300,000 individuals

- Mandatory quarantine/isolation areas for mass exposures spotted. China develops stadium in $24 \mathrm{~h}$

- Free testing. Provide free and easily accessible testing

- Reduced human to human transmission by social distances and personal protection gears

- Adopt hygiene, e.g., alcohol-based hand sanitizers

- Wear masks when going outside

- Support working from home or online. Several countries support online businesses

- Lockdown. China essentially implemented a countrywide shutdown

Acknowledgements The authors are thankful to the Institute of Research and Consulting Studies at King Khalid University (KKU), Abha-Asir, and Kingdom of Saudi Arabia for supporting this research through grant number 36-72-S-2020. Also, this research has been supported by the Tehran University of Medical Sciences.

Authors' contributions Data curation: A H Khan, N A Khan, A al Mahmoud, S Roy. Formal analysis: A H Khan, N A Khan, S S Ali. Funding acquisition: V Tirth, S Islam, G Das. Investigation, editing, writing and reviewing: A H Khan, N A Khan, M Akram, L Hameed, V Tirth. Resources: N A Khan, A H Khan, M Akram. Supervision: M H Dehghani, S Ahmad, M Fawzy, S S Ali, S Roy. Writing-original draft: A H Khan, M H Dehghani, N A Khan, S Roy, A EL D Mahmoud, S S Ali. Writing-review and editing: M H Dehghani, S Roy, A H Khan, N A Khan.

\section{Declarations}

Conflict of interest The authors declare that they have no competing interests.

Ethical approval Not applicable.

Consent for publication Not applicable.

\section{References}

AbdelHamid AA, Al-Ghobashy MA, Fawzy M et al (2013) Phytosynthesis of $\mathrm{Au}, \mathrm{Ag}$, and $\mathrm{Au}-\mathrm{Ag}$ bimetallic nanoparticles using aqueous extract of sago pondweed (Potamogeton pectinatus $L$.). ACS Sustain Chem Eng 1:1520-1529. https://doi.org/10.1021/ sc4000972

Abdul W, Muhammad A, Atta Ullah K et al (2020) Role of nanotechnology in diagnosing and treating COVID-19 during the pandemi. Int J Clin Virol 4:065-070. https://doi.org/10.29328/ journal.ijcv.1001017

Alfaraj SH, Al-Tawfiq JA, Assiri AY et al (2019) Clinical predictors of mortality of Middle East respiratory syndrome coronavirus (MERS-CoV) infection: a cohort study. Travel Med Infect Dis 29:48-50. https://doi.org/10.1016/j.tmaid.2019.03.004

Alpaslan Kocamemi B, Kurt H, Sait A et al (2020) SARS-CoV-2 Detection in istanbul wastewater treatment plant sludges. medRxiv. https://doi.org/10.1101/2020.05.12.20099358

Amirian ES (2020) Potential fecal transmission of SARS-CoV-2: current evidence and implications for public health. Int J Infect Dis 95:363-370. https://doi.org/10.1016/j.ijid.2020.04.057

Andersen KG, Rambaut A, Lipkin WI et al (2020) The proximal origin of SARS-CoV-2. Nat Med 26:450-452. https://doi.org/10.1038/ s41591-020-0820-9

Assiri A, Al-Tawfiq JA, Al-Rabeeah AA et al (2013) Epidemiological, demographic, and clinical characteristics of 47 cases of Middle East respiratory syndrome coronavirus disease from Saudi Arabia: a descriptive study. Lancet Infect Dis 13:752-761. https:// doi.org/10.1016/S1473-3099(13)70204-4

Baranwal A, Mahapatra S, Purohit B, Roy S, Chandra P (2020) Insights into novel coronavirus and COVID-19 outbreak. Springer, Singapore, pp 1-17

Bonafè M, Prattichizzo F, Giuliani A et al (2020) Inflamm-aging: why older men are the most susceptible to SARS-CoV-2 complicated outcomes. Cytokine Growth Factor Rev 53:33-37. https://doi. org/10.1016/j.cytogfr.2020.04.005

Cagno V, Andreozzi P, D'Alicarnasso M et al (2018) Broad-spectrum non-toxic antiviral nanoparticles with a virucidal inhibition mechanism. Nat Mater 17:195-203. https://doi.org/10.1038/ nmat5053

Carraturo F, Del Giudice C, Morelli M et al (2020) Persistence of SARS-CoV-2 in the environment and COVID-19 transmission risk from environmental matrices and surfaces. Environ Pollut 265:115010. https://doi.org/10.1016/j.envpol.2020.115010

Casanova LM, Jeon S, Rutala WA et al (2010) Effects of air temperature and relative humidity on coronavirus survival on surfaces. Appl Environ Microbiol 76:2712-2717. https://doi.org/10.1128/ AEM.02291-09

CDC (2020) Coronavirus disease 2019 (COVID-19)

Chan KH, Peiris JSM, Lam SY et al (2011) The effects of temperature and relative humidity on the viability of the SARS coronavirus. Adv Virol. https://doi.org/10.1155/2011/734690 
Chan JFW, To KKW, Tse H et al (2013) Interspecies transmission and emergence of novel viruses: lessons from bats and birds. Trends Microbiol 21:544-555. https://doi.org/10.1016/j.tim.2013.05.005

Chandra P, Roy S (2020) Diagnostic strategies for COVID-19 and other coronaviruses. Springer, Singapore

Chen Y-N, Hsueh Y-H, Hsieh C-T et al (2016) Antiviral activity of graphene-silver nanocomposites against non-enveloped and enveloped viruses. Int J Environ Res Public Health 13:430. https://doi. org/10.3390/ijerph13040430

Chen H, Guo J, Wang C et al (2020a) Clinical characteristics and intrauterine vertical transmission potential of COVID-19 infection in nine pregnant women: a retrospective review of medical records. Lancet 395:809-815. https://doi.org/10.1016/S01406736(20)30360-3

Chen N, Zhou M, Dong X et al (2020b) Epidemiological and clinical characteristics of 99 cases of 2019 novel coronavirus pneumonia in Wuhan, China: a descriptive study. Lancet 395:507-513. https://doi.org/10.1016/S0140-6736(20)30211-7

Chin AWH, Chu JTS, Perera MRA et al (2020) Stability of SARS$\mathrm{CoV}-2$ in different environmental conditions. Lancet Microbe 1:e10. https://doi.org/10.1016/S2666-5247(20)30003-3

Cho SY, Kang JM, Ha YE et al (2016) MERS-CoV outbreak following a single patient exposure in an emergency room in South Korea: an epidemiological outbreak study. Lancet 388:994-1001. https://doi.org/10.1016/S0140-6736(16)30623-7

Choi H, Chatterjee P, Lichtfouse E et al (2021) Classical and alternative disinfection strategies to control the COVID-19 virus in healthcare facilities: a review. Environ Chem Lett. https://doi.org/10. 1007/s10311-021-01180-4

Chowell G, Abdirizak F, Lee S et al (2015) Transmission characteristics of MERS and SARS in the healthcare setting: a comparative study. BMC Med 13:210. https://doi.org/10.1186/ s12916-015-0450-0

Cui J, Eden J-S, Holmes EC, Wang L-F (2013) Adaptive evolution of bat dipeptidyl peptidase 4 (dpp4): implications for the origin and emergence of Middle East respiratory syndrome coronavirus. Virol J 10:304. https://doi.org/10.1186/1743-422X-10-304

Culp WC (2020) Coronavirus disease 2019: in-home isolation room construction. A\&A Pract 14(6):e01218

Dai H, Han J, Lichtfouse E (2020) Who is running faster, the virus or the vaccine? Environ Chem Lett 18:1761-1766. https://doi.org/ 10.1007/s10311-020-01110-w

Drosten C, Seilmaier M, Corman VM et al (2013) Clinical features and virological analysis of a case of Middle East respiratory syndrome coronavirus infection. Lancet Infect Dis 13:745-751. https://doi.org/10.1016/S1473-3099(13)70154-3

Elkholy AA, Grant R, Assiri A et al (2020) MERS-CoV infection among healthcare workers and risk factors for death: retrospective analysis of all laboratory-confirmed cases reported to WHO from 2012 to 2 June 2018. J Infect Public Health 13:418-422. https://doi.org/10.1016/j.jiph.2019.04.011

Emanuel EJ, Persad G, Upshur R et al (2020) Fair allocation of scarce medical resources in the time of Covid-19. N Engl J Med. https:// doi.org/10.1056/NEJMsb2005114

Ge X-Y, Li J-L, Yang X-L et al (2013) Isolation and characterization of a bat SARS-like coronavirus that uses the ACE2 receptor. Nature 503:535-538. https://doi.org/10.1038/nature12711

Gomathi M, Rajkumar PV, Prakasam A, Ravichandran K (2017) Green synthesis of silver nanoparticles using datura stramonium leaf extract and assessment of their antibacterial activity. Resour Technol 3:280-284. https://doi.org/10.1016/j.reffit.2016.12.005

Gorrasi G, Sorrentino A, Lichtfouse E (2020) Back to plastic pollution in COVID times. Environ Chem Lett 19:1-4. https://doi. org/10.1007/s10311-020-01129-Z

Guan Y, Zheng BJ, He YQ et al (2003) Isolation and characterization of viruses related to the SARS coronavirus from animals in southern China. Science 302:276-278. https://doi.org/10. 1126/science. 1087139

Haramoto E, Malla B, Thakali O, Kitajima M (2020) First environmental surveillance for the presence of SARS-CoV-2 RNA in wastewater and river water in Japan. Sci Total Environ 737:140405. https://doi.org/10.1016/j.scitotenv.2020.140405

He S, Han J, Lichtfouse E (2021) Backward transmission of COVID19 from humans to animals may propagate reinfections and induce vaccine failure. Environ Chem Lett. https://doi.org/10. 1007/s10311-020-01140-4

Huang D, Yu H, Wang T et al (2020) Efficacy and safety of umifenovir for coronavirus disease 2019 (COVID-19): a systematic review and meta-analysis. J Med Virol. https://doi.org/10.1002/ jmv.26256.10.1002/jmv.26256

Hui DS, Azhar EI, Kim YJ et al (2018) Middle East respiratory syndrome coronavirus: risk factors and determinants of primary, household, and nosocomial transmission. Lancet Infect Dis 18:e217-e227. https://doi.org/10.1016/S1473-3099(18) 30127-0

Iannazzo D, Pistone A, Ferro S et al (2018) Graphene quantum dots based systems as HIV inhibitors. Bioconjug Chem 29:30843093. https://doi.org/10.1021/acs.bioconjchem. 8 b00448

Innocenzi P, Stagi L (2020) Carbon-based antiviral nanomaterials: graphene, C-dots, and fullerenes a perspective. Chem Sci 11:6606-6622. https://doi.org/10.1039/D0SC02658A

Ip M, Chan PKS, Lee N et al (2004) Seroprevalence of antibody to severe acute respiratory syndrome (SARS)-associated coronavirus among health care workers in SARS and non-SARS medical wards. Clin Infect Dis 38:e116-e118. https://doi.org/ $10.1086 / 421019$

Ji JS (2020) Origins of MERS-CoV, and lessons for 2019-nCoV. Lancet Planet Heal. https://doi.org/10.1016/S2542-5196(20) 30032-2

Ji W, Wang W, Zhao X et al (2020) Cross-species transmission of the newly identified coronavirus 2019-nCoV. J Med Virol 92:433440. https://doi.org/10.1002/jmv.25682

Jokanovic V, Zivkovic M, Zdravkovic N (2020) A new approach to extraordinary efficient protection against COVID 19 based on nanotechnology. Stomatol Glas Srb Dent J 67:100-109. https:// doi.org/10.2298/sgs2002100j

Kampf G, Todt D, Pfaender S, Steinmann E (2020) Persistence of coronaviruses on inanimate surfaces and their inactivation with biocidal agents. J Hosp Infect 104:246-251. https://doi.org/10. 1016/j.jhin.2020.01.022

Khan NA, Ahmed S, Farooqi IH et al (2020) Chapter 2: Advances and application of nano-technology. In: Sachdeva A, Sharma P (eds) Smart nanotechnology with applications, 1 st edn. CRC Press, $p$ 310. https://doi.org/10.1201/9781003097532

Khan AH, Khan NA, Ahmed S et al (2020) Application of advanced oxidation processes followed by different treatment technologies for hospital wastewater treatment. J Clean Prod. https://doi.org/ 10.1016/j.jclepro.2020.122411

Khanna RC, Honavar SG (2020) All eyes on coronavirus-what do we need to know as ophthalmologists. Indian J Ophthalmol 68:549553. https://doi.org/10.4103/ijo.IJO_516_20

Kong W-H, Li Y, Peng M-W et al (2020) SARS-CoV-2 detection in patients with influenza-like illness. Nat Microbiol 5:675-678. https://doi.org/10.1038/s41564-020-0713-1

Kontou PI, Braliou GG, Dimou NL, Nikolopoulos G, Bagos PG (2020) Antibody tests in detecting SARS-CoV-2 infection: a meta-analysis. Diagnostics 10(5):319

Kumar P, Mishra S, Malik A, Satya S (2012) Insecticidal evaluation of essential oils of citrus sinensis L. (Myrtales: Myrtaceae) against housefly, Musca domestica L. (Diptera: Muscidae). Parasitol Res 110:1929-1936. https://doi.org/10.1007/s00436-011-2719-3 
Kumar M, Patel AK, Shah AV et al (2020) The first proof of the capability of wastewater surveillance for COVID-19 in India through the detection of the genetic material of SARS-CoV-2. medRxiv. https://doi.org/10.1101/2020.06.16.20133215

Kumar NS, Chintagunta AD, Kumar SPJ, Roy S, Kumar M (2020) Immunotherapeutics for Covid-19 and post vaccination surveillance. 3 Biotech 10(12):527

Lai MYY, Cheng PKC, Lim WWL (2005) Survival of severe acute respiratory syndrome coronavirus. Clin Infect Dis 41:e67-e71. https://doi.org/10.1086/433186

Lau SKP, Zhang L, Luk HKH et al (2018) Receptor usage of a novel bat lineage $\mathrm{C}$ betacoronavirus reveals evolution of Middle East respiratory syndrome-related coronavirus spike proteins for human dipeptidyl peptidase 4 binding. J Infect Dis 218:197-207. https://doi.org/10.1093/infdis/jiy018

Lee I-K, Wang C-C, Lin M-C et al (2020) Effective strategies to prevent coronavirus disease-2019 (COVID-19) outbreak in hospital. J Hosp Infect. https://doi.org/10.1016/j.jhin.2020.02.022

Li F (2015) Receptor recognition mechanisms of coronaviruses: a decade of structural studies. J Virol 89:1954-1964. https://doi.org/ 10.1128/JVI.02615-14

Li W, Shi Z, Yu M et al (2005) Bats are natural reservoirs of SARS-like coronaviruses. Science 310:676-679. https://doi.org/10.1126/ science. 1118391

Lisboa Bastos M, Tavaziva G, Abidi SK et al (2020) Diagnostic accuracy of serological tests for covid-19: systematic review and meta-analysis. BMJ 370:m2516. https://doi.org/10.1136/bmj. $\mathrm{m} 2516$

Liu Y, Gayle AA, Wilder-Smith A, Rocklöv J (2020) The reproductive number of COVID-19 is higher compared to SARS coronavirus. J Travel Med. https://doi.org/10.1093/jtm/taaa021

Lu H, Stratton CW, Tang YW (2020) Outbreak of pneumonia of unknown etiology in Wuhan, China: the mystery and the miracle. J Med Virol 92:401-402. https://doi.org/10.1002/jmv.25678

Lu R, Zhao X, Li J et al (2020) Genomic characterisation and epidemiology of 2019 novel coronavirus: implications for virus origins and receptor binding. Lancet 395:565-574. https://doi.org/10. 1016/S0140-6736(20)30251-8

Mahapatra S, Baranwal A, Purohit B, Roy S, Mahto SK, Chandra P (2020) Advanced biosensing methodologies for ultrasensitive detection of human coronaviruses. Springer, Singapore, pp 19-36

Mahmoud AED (2020) Graphene-based nanomaterials for the removal of organic pollutants: insights into linear versus nonlinear mathematical models. J Environ Manage 270:110911. https://doi.org/ 10.1016/j.jenvman.2020.110911

Mazhar MA, Khan NA, Ahmed S et al (2020) Chlorination disinfection by-products in municipal drinking water-a review. J Clean Prod 273:123159. https://doi.org/10.1016/j.jclepro.2020.123159

Medema G, Heijnen L, Elsinga G et al (2020) Presence of SARScoronavirus-2 in sewage. medRxiv 78(9):373. https://doi.org/10. 1101/2020.03.29.20045880

Memish ZA, Ahmed Y, Alqahtani SA, Ebrahim SH (2020) Pausing super spreader events for COVID-19 mitigation: international hajj pilgrimage cancellation. Travel Med Infect Dis. https://doi. org/10.1016/j.tmaid.2020.101817

Misra A (2020) Doctors and healthcare workers at frontline of covid 19 epidemic: admiration, a pat on the back, and need for extreme caution. Diabetes Metab Syndr Clin Res Rev. https://doi.org/10. 1016/j.dsx.2020.03.006

Momattin H, Al-Ali AY, Al-Tawfiq JA (2019) A systematic review of therapeutic agents for the treatment of the Middle East respiratory syndrome coronavirus (MERS-CoV). Travel Med Infect Dis 30:9-18. https://doi.org/10.1016/j.tmaid.2019.06.012

Mousazadeh M, Paital B, Naghdali Z et al (2021) Positive environmental effects of the coronavirus 2020 episode: a review. Environ Dev Sustain. https://doi.org/10.1007/s10668-021-01240-3
Nikaeen G, Abbaszadeh S, Yousefinejad S (2020) Application of nanomaterials in treatment, anti-infection and detection of coronaviruses. Nanomedicine 15:1501-1512. https://doi.org/10.2217/ nnm-2020-0117

Nomoto H, Ishikane M, Katagiri D et al (2020) Cautious handling of urine from moderate to severe COVID-19 patients. Am J Infect Control 48:969-971. https://doi.org/10.1016/j.ajic.2020.05.034

Patel M (2020) antimicrobial paper embedded with nanoparticles as spread-breaker for corona virus. Am J Nanotechnol Nanomed $3: 1-012$

Pavli A, Tsiodras S, Maltezou HC (2014) Middle East respiratory syndrome coronavirus (MERS-CoV): prevention in travelers. Travel Med Infect Dis 12:602-608. https://doi.org/10.1016/j. tmaid.2014.10.006

Peck KR (2020) Early diagnosis and rapid isolation: response to COVID-19 outbreak in Korea. Clin Microbiol Infect 26:805-807. https://doi.org/10.1016/j.cmi.2020.04.025

Pinon A, Vialette M (2018) Survival of viruses in water. Intervirology 61:214-222. https://doi.org/10.1159/000484899

Prabha S, Durgalakshmi D, Rajendran S, Lichtfouse E (2020) Plantderived silica nanoparticles and composites for biosensors, bioimaging, drug delivery and supercapacitors: a review. Environ Chem Lett. https://doi.org/10.1007/s10311-020-01123-5

Purohit B, Kumar A, Mahato K, Roy S, Chandra P (2019) Chapter 9-Cancer cytosensing approaches in miniaturized settings based on advanced nanomaterials and biosensors. In: Maurya PK, Singh S (eds) Nanotechnology in modern animal biotechnology. Elsevier, Amsterdam, pp 133-147

Rabaan AA, Al-Ahmed SH, Haque S et al (2020) SARS-CoV-2, SARS$\mathrm{CoV}$, and MERS-COV: a comparative overview. Le Infez Med 28:174-184

Rahman A, Sarkar A (2019) Risk factors for fatal Middle East respiratory syndrome coronavirus infections in Saudi Arabia: analysis of the WHO line list, 2013-2018. Am J Public Health 109:12881293. https://doi.org/10.2105/AJPH.2019.305186

Randazzo W, Truchado P, Cuevas-Ferrando E et al (2020) SARSCoV-2 RNA in wastewater anticipated COVID-19 occurrence in a low prevalence area. Water Res 181:115942. https://doi.org/ 10.1016/j.watres.2020.115942

Reichberg SB, Mitra PP, Haghamad A, Ramrattan G, Crawford JM, Northwell C-RC, Berry GJ, Davidson KW, Drach A, Duong S, Juretschko S, Maria NI, Yang Y, Ziemba YC (2020) Rapid emergence of SARS-CoV-2 in the greater New York metropolitan area: geolocation, demographics, positivity rates, and hospitalization for 46793 persons tested by northwell health. Clin Infect Dis 71(12):3204-3213

Robba C, Battaglini D, Pelosi P, Rocco PRM (2020) Multiple organ dysfunction in SARS-CoV-2: MODS-CoV-2. Expert Rev Respir Med. https://doi.org/10.1080/17476348.2020.1778470

Rodriguez-Manzano J, Malpartida-Cardenas K, Moser N, Pennisi I, Cavuto M, Miglietta L, Moniri A, Penn R, Satta G, Randell P, Davies F, Bolt F, Barclay W, Holmes A, Georgiou P (2021) Handheld point-of-care system for rapid detection of SARS-CoV-2 extracted RNA in under $20 \mathrm{~min}$. ACS Cent Sci 7(2):307-317

Roy S, Baranwal A (2020) Diverse molecular techniques for early diagnosis of COVID-19 and other coronavirueses. In: Chandra P, Roy $\mathrm{S}$ (eds) In the book of diagnostic strategies for COVID-19 and other coronaviruses. Springer Nature, Singapore, pp 135-159

Salmiati AS, Salim MR, Kuch ABH, Nur THH (2017) A review of silver nanoparticles: research, trends global consumption, synthesis, properties, and future challenges. J Chin Chem Soc 64:732756. https://doi.org/10.1002/jccs.201700067

Sarkar S, Ponce NT, Banerjee A et al (2020) Green polymeric nanomaterials for the phtocatalytic degradation of dyes: a review. 
Environ Chem Lett 18:1569-1580. https://doi.org/10.1007/ s10311-020-01021-w

Sen-Crowe B, Sutherland M, McKenney M, Elkbuli A (2021) The Florida COVID-19 mystery: lessons to be learned. Am J Emerg Med. https://doi.org/10.1016/j.ajem.2020.08.009

Sharma VK, Jinadatha C, Lichtfouse E (2020) Environmental chemistry is most relevant to study coronavirus pandemics. Environ Chem Lett 18:993-996. https://doi.org/10.1007/s10311-020-01017-6

Sharma VK, Jinadatha C, Lichtfouse E et al (2021) COVID-19 epidemiologic surveillance using wastewater. Environ Chem Lett. https://doi.org/10.1007/s10311-021-01188-w

Shereen MA, Khan S, Kazmi A et al (2020) COVID-19 infection: origin, transmission, and characteristics of human coronaviruses. J Adv Res 24:91-98. https://doi.org/10.1016/j.jare.2020.03.005

Shetti NP, Malode SJ, Roy S, Chandra P, Reddy KR, Chatterjee S (2020) 11-Electroanalytical techniques for investigating biofilms: applications in biosensing and biomolecular interfacing. In: Kanchi S, Sharma D (eds) Nanomaterials in diagnostic tools and devices. Elsevier, Amsterdam, pp 293-329

Singh L, Kruger HG, Maguire GEM et al (2017) The role of nanotechnology in the treatment of viral infections. Ther Adv Infect Dis 4:105-131. https://doi.org/10.1177/2049936117713593

Sizun J, Yu MWN, Talbot PJ (2000) Survival of human coronaviruses 229E and OC43 in suspension and after drying on surfaces: a possible source of hospital-acquired infections. J Hosp Infect 46:55-60. https://doi.org/10.1053/jhin.2000.0795

Sohrabi C, Alsafi Z, O'Neill N et al (2020) World Health Organization declares global emergency: a review of the 2019 novel coronavirus (COVID-19). Int J Surg 76:71-76. https://doi.org/10.1016/j. ijsu.2020.02.034

Sportelli MC, Izzi M, Kukushkina EA et al (2020) Can nanotechnology and materials science help the fight against SARS-CoV-2? Nanomater 10(4):802

Staroverov SA, Vidyasheva IV, Gabalov KP et al (2011) Immunostimulatory effect of gold nanoparticles conjugated with transmissible gastroenteritis virus. Bull Exp Biol Med 151:436. https://doi.org/ 10.1007/s10517-011-1350-8

Sudha A, Jeyakanthan J, Srinivasan P (2017) Green synthesis of silver nanoparticles using lippia nodiflora aerial extract and evaluation of their antioxidant, antibacterial and cytotoxic effects. Resour Technol 3:506-515. https://doi.org/10.1016/j.reffit.2017.07.002

Sun S, Han J (2020) Unflushable or missing toilet paper, the dilemma for developing communities during the COVID-19 episode. Environ Chem Lett 19:711-717. https://doi.org/10.1007/ s10311-020-01064-z

Talebian S, Wallace GG, Schroeder A et al (2020) Nanotechnologybased disinfectants and sensors for SARS-CoV-2. Nat Nanotechnol 15:618-621. https://doi.org/10.1038/s41565-020-0751-0

Tang B, Bragazzi NL, Li Q et al (2020) An updated estimation of the risk of transmission of the novel coronavirus (2019-nCov). Infect Dis Model 5:248-255. https://doi.org/10.1016/j.idm.2020.02.001

van Doremalen N, Bushmaker T, Munster VJ (2013) Stability of Middle East respiratory syndrome coronavirus (MERS-CoV) under different environmental conditions. Eurosurveillance 18:1-4. https://doi.org/10.2807/1560-7917.ES2013.18.38.20590

van Doremalen N, Bushmaker T, Morris DH et al (2020) Aerosol and surface stability of SARS-CoV-2 as compared with SARSCoV-1. N Engl J Med. https://doi.org/10.1056/NEJMc2004973

Vasickova P, Pavlik I, Verani M, Carducci A (2010) Issues concerning survival of viruses on surfaces. Food Environ Virol 2:24-34. https://doi.org/10.1007/s12560-010-9025-6

Vazquez-Munoz R, Lopez-Ribot JL (2020) Nanotechnology as an alternative to reduce the spread of COVID-19. Challenges 11(2):15

Wang X-W, Li J-S, Jin M et al (2005) Study on the resistance of severe acute respiratory syndrome-associated coronavirus. J Virol
Methods 126:171-177. https://doi.org/10.1016/j.jviromet.2005. 02.005

Wang M, Yan M, Xu H et al (2005) SARS-CoV infection in a restaurant from palm civet. Emerg Infect Dis 11:1860-1865. https://doi.org/ 10.3201/eid1112.041293

Wang H, Zhu W, Feng L et al (2018) Nanoscale covalent organic polymers as a biodegradable nanomedicine for chemotherapyenhanced photodynamic therapy of cancer. Nano Res 11:32443257. https://doi.org/10.1007/s12274-017-1858-y

Wang D, Hu B, Hu C et al (2020a) Clinical characteristics of 138 hospitalized patients with 2019 novel coronavirus-infected pneumonia in Wuhan, China. JAMA-J Am Med Assoc 323:1061-1069. https://doi.org/10.1001/jama.2020.1585

Wang J, Zhao S, Liu M et al (2020b) ACE2 expression by colonic epithelial cells is associated with viral infection, immunity and energy metabolism. medRxiv 9(1):221. https://doi.org/10.1101/ 2020.02.05.20020545

Wang L, Li M, Yu S et al (2020c) Unexpected rise of ozone in urban and rural areas, and sulfur dioxide in rural areas during the coronavirus city lockdown in Hangzhou, China: implications for air quality. Environ Chem Lett 18:1713-1723. https://doi.org/10. 1007/s10311-020-01028-3

Wang X, Sun S, Zhang B, Han J (2020d) Solar heating to inactivate thermal-sensitive pathogenic microorganisms in vehicles: application to COVID-19. Environ Chem Lett. https://doi.org/10. 1007/s10311-020-01132-4

Wang X, Han J, Lichtfouse E (2020e) Unprotected mothers and infants breastfeeding in public amenities during the COVID-19 pandemic. Environ Chem Lett 18:1447-1450. https://doi.org/10. 1007/s10311-020-01054-1

Watkins J (2020) Preventing a covid-19 pandemic. BMJ 368:1-2. https://doi.org/10.1136/bmj.m810

WHO (2019) Middle East respiratory syndrome coronavirus (MERSCoV)-The Kingdom of Saudi Arabia. Saudi Arabia

WHO (2020) Coronavirus disease 2019. World Health Organ 2019:2633. https://doi.org/10.1001/jama.2020.2633

Wu A, Peng Y, Huang B et al (2020) Genome composition and divergence of the novel coronavirus $(2019-\mathrm{nCoV})$ originating in China. Cell Host Microbe 27:325-328. https://doi.org/10.1016/j. chom.2020.02.001

Wu F, Xiao A, Zhang J et al (2020) (2020b) SARS-CoV-2 titers in wastewater are higher than expected from clinically confirmed cases. medRxiv 04(05):20051540. https://doi.org/10.1101/2020. 04.05.20051540

Wu Y-C, Chen C-S, Chan Y-J (2020) The outbreak of COVID-19: an overview. J Chin Med Assoc 83(3):217-220

Xiao J, Fang M, Chen Q, He B (2020) SARS, MERS and COVID-19 among healthcare workers: a narrative review. J Infect Public Health 13:843-848. https://doi.org/10.1016/j.jiph.2020.05.019

Yang W, Dang X, Wang Q et al (2020) Rapid detection of SARSCoV-2 using reverse transcription RT-LAMP method. medRxiv 395(10224):565. https://doi.org/10.1101/2020.03.02.20030130

Ye S, Shao K, Li Z et al (2015) Antiviral activity of graphene oxide: how sharp edged structure and charge matter. ACS Appl Mater Interfaces 7:21571-21579. https://doi.org/10.1021/acsami.5b068 76

Ye Z-W, Yuan S, Yuen K-S et al (2020) Zoonotic origins of human coronaviruses. Int J Biol Sci 16:1686-1697. https://doi.org/10. $7150 / \mathrm{ijbs} .45472$

Yépiz-Gómez MS, Gerba CP, Bright KR (2013) Survival of respiratory viruses on fresh produce. Food Environ Virol 5:150-156. https:// doi.org/10.1007/s12560-013-9114-4

Yuen K-S, Ye Z-W, Fung S-Y et al (2020) SARS-CoV-2 and COVID19: the most important research questions. Cell Biosci 10:40. https://doi.org/10.1186/s13578-020-00404-4 
Zhang C, Zheng W, Huang X et al (2020) Protein structure and sequence re-analysis of 2019-nCoV genome does not indicate snakes as its intermediate host or the unique similarity between its spike protein insertions and HIV-1. J Proteome Res 19(4):1351-1360

Zhang R, Li Y, Zhang AL, Wang Y, Molima MJ (2020) Identifying airborne transmission as the dominant route for the spread of COVID-19. Proc Natl Acad Sci 117(26):14857-14863. https:// doi.org/10.1073/pnas.2009637117

Zhu X, Wang X, Han L et al (2020) Reverse transcription loop-mediated isothermal amplification combined with nanoparticles-based biosensor for diagnosis of COVID-19. medRxiv. https://doi.org/ $10.1101 / 2020.03 .17 .20037796$

Publisher's Note Springer Nature remains neutral with regard to jurisdictional claims in published maps and institutional affiliations. 